\title{
[23] PALAEOMAgNETIC AND PALAEOCLIMATOLOGICAL ASPECTS OF POLAR WANDERING
}

\author{
by \\ E. IRVING
}

\section{Introduction}

It is now generally recognized that measurements of the directions of magnetisation of samples from a magnetically stable rock formation allow the direction of the Earth's magnetic field at the time when the rock was formed to be determined.

The direction of the Earth's magnetic field has been recorded at observatories in many places over the past few hundred years, and from an analysis of these records it is possible to recognise two components in the geomagnetic field: the first being approximately that of a dipole at the centre of the Earth with its axis along the axis of rotation, and the second a much smaller non-dipole component which undergoes variations with periods of the order of hundreds of years. Thus [24] under present conditions, the Earth's field, when averaged over a period of some hundreds of years, is that of a dipole directed approximately along the axis of rotation. [T] he term «magnetic axis » will be used in this sense, as the axis of the mean dipole field, ... The term «magnetic pole» will be used for the intersection of this axis with the Earth's surface....

On these definitions, the magnetic axis in the past few centuries has coincided approximately with the axis of rotation, and the magnetic pole has been near to the present geographic pole. The work of Hospers and others, which is discussed in $\S 3$, has shown that the same result holds as far back as the Miocene ... , and on any dynamo theory of the Earth's magnetic field [Bullard (1949), Runcorn (1954)] it might be expected to have held at all times in the past. ... Also, . . . it is reasonable to assume that if this coincidence has held throughout geological time, this field has also always been a dipole field.

On the assumption of a dipole field the pole positions deduced from palaeomagnetie observations from rocks of many geological ages in North-Western Europe, North America, India and Australia are given in $\S \S 4$ and 5 . These pole positions are very different from the present pole of the Earth, and in some cases fall on continuous curves (Figures 1 and 2).

The simplest hypothesis of polar wandering is that the magnetic and rotational axes have coincided throughout geological time, so that the curve of Fig. 1 is also the path of the geographic North pole relative to the crust: the outer layers of the Earth are assumed to have moved as a whole relative to the rotation axis, and GOLD (1955) has shown that small changes in the distribution of mass in the crust, for example, those involved in epeirogeny can cause such a movement. If this hypothesis is true, three consequences follow:

(i) The palaeoclimate at any place should be broadly consistent with the latitude deduced from the pole positions obtained from palaeomagnetic observations at the same place. Thus, the palaeoclimatic evidence is vital for testing the assumption that the Earth's geographic and magnetic axes have been coincident throughout geological time. This matter is discussed in $\S 6$.

(ii) The same path of pole movement should be obtained from magnetic observations at all points on the Earth.

(iii) The indications of palaeoclimatology at all places on the Earth throughout geological time should be consistent with the latitude deduced from this path of pole motion.

[25] However, if relative movement of land-masses has taken place, the magnetic and rotational axes remaining coincident, it follows that the first of the above points will hold, hut the others will not; the curve of pole motion given from results from different continents will not be the same, and the palaeoclimatic evidence at all points on the Earth will not agree with the pole positions given by magnetic results from any single continent. . . The palaeomagnetic results relevant to this point are discussed in $\S \S 4$ and 5. Also, in this connection, a test of point (iii) is interesting, namely, the comparison of palaeoclimates all over the Earth with the latitudes given by the pole position deduced from palaeomagnetic observations in a single continent. This comparison is made in $\S 7$.

\section{The calculation of the ancient pole position}

The directions of magnetisation measured for individual specimens from the same geological formation show a considerable scatter so that it is necessary to discuss all results statistically.

Suppose that $N$ specimens are taken from a given formation. Taking $x, y$, and $z$-axes, respectively, Northwards, Eastwards and downwards, the direction of magnetisation of the $r$-th specimen is specified by its $\operatorname{dip} \theta_{r}$, which is the angle between its direction and the $x y$-plane (measured positively downwards) and its declination $\Phi_{r}$, which is the angle between the $x$-axis and the projection of the direction on the $x y$-plane (measured clockwise). The direction cosines $\left(l_{r}, m_{r}, n_{r}\right)$ of the direction of magnetisation of the specimen are then given by

$$
l_{r}=\cos \Phi_{r} \cos \theta_{r} \quad m_{r}=\sin \Phi_{r} \cos \theta_{r} \quad n_{r}=\sin \theta_{r}
$$

If $(\lambda, \mu, v)$ are the direction cosines of the true mean direction of magnetisation of the formation. Fisher (1953) has suggested that the measured directions of magnetization of the individual specimens will, when regarded as points on a unit sphere, be distributed over the sphere with probability density

$$
\chi / 4 \pi \sinh \chi \exp \{\chi \cos \psi\}
$$

where $\psi$ is the angle between the direction $(\lambda, \mu, v)$ and that of the magnetisation of the specimen. The parameter $\chi$ determines the dispersions of the points: if $\chi=0$, they axe randomly distributed; for large values of $\chi$ they cluster about $(\lambda, \mu, v)$. 
Fisher (1953) has shown that the best estimate of $(\lambda, \mu, v)$ is the mean $(l, m, n)$ of the direction cosines of the specimens, that is,

$$
1=\left(\sum_{n=1}^{N} 1_{r}\right) / R, m=\left(\sum_{n=1}^{N} m_{r}\right) / R, 1=\left(\sum_{n=1}^{N} m_{r}\right) / R \text {, }
$$

[26] where

$$
R=\left\{\left(\sum_{r=1}^{N} 1_{r}\right)^{2}+\left(\sum_{r=1}^{N} m_{r}\right)^{2}+\left(\sum_{r=1}^{N} n_{r}\right)^{2}\right\}^{1 / 2}
$$

Also, the best estimate $k$ of the dispersion parameter $\div$ obtainable from this sample is given by

$$
k=(N-1) /(N-R)
$$

In the present context what is needed is an indication of the accuracy of the estimate $(l, m, n)$ of the true mean direction $(\lambda, \mu, v)$. This may be specified by the semi-vertical angle $\alpha$ of the cone about the mean direction $(l, m, n)$ such that the probability of the true mean direction $(\lambda, \mu, v)$ derived from the $N$ samples lying outside it is $P$. This has been shown by Fisher to be given by

$$
\cos \alpha=1-(N-R) / R\left\{P^{-1 /(n-1)}-1\right\}
$$

This angle of confidence with $P=0.05$ will always be used here.

When the mean direction of magnetisation of a formation has been found and specified by its dip and declination, the direction of the dipole in whose field it was magnetized may be calculated. The declination gives the direction in which the former pole lay, and the $\operatorname{dip} \theta$ is related to the former geomagnetic co-latitude $p$ by the equation of a line of force in a dipole field, namely,

$$
\cot p=1 / 2 \tan \Phi
$$

The co-latitude and longitude $a$ and $b$ of the former pole and antipole in present day geographical co-ordinates may be obtained by solution of the appropriate spherical triangles from the formulae and

$$
\cos a=\cos c \cdot \cos p+\sin c \cdot \sin p \cdot \cos \Phi
$$

$$
\sin (b-d)=(\sin p \cdot \sin \Phi) / \sin \alpha
$$

where $c$ and $d$ are the geographical co-latitude and longitude of the sampling area.

Since the direction of magnetisation may lie anywhere within the cone of semi-vertical angle $\alpha$ with a probability of $1-P$, there will be possible errors in the calculated position of the pole. An error $\alpha$ in the dip corresponds by equation (7) to an error $\delta p$ in $p$ given by

$$
\delta p=1 / 2 \alpha\left(1+3 \cos ^{2} p\right),
$$

[27] and an error $\alpha$ in declination corresponds to a displacement $\delta m$ of the pole in the perpendicular direction, where

$$
\delta m=\alpha(\sin p / \cos \Phi) .
$$

Thus $\delta m$ and $\delta p$ are the semi-vertical angles of an oval cone of confidence in which the probability that the actual pole lies is $1-P$. In the tables of magnetic results given later the errors will always be specified by $\alpha, \delta p$ and $\delta m$ for $P=0.05$.

[Magnetic reversals will not affect the foregoing arguments. Magnetically stable rocks can be identified and only such rocks have been relied on in the study.]

\section{The Earth's Magnetic Field in Miocene and Later} Times

It was remarked in $\S 1$ that in recent centuries the Earth's magnetic field, when averaged over a few hundred years, is that of a dipole whose axis, the magnetic axis, coincides approximately with the axis of rotation, HOSPERS (1955) has shown [using CHEVALLIER's data of 1925] that the same result follows from measurements of the direction of magnetisation [28] in the lavas of Mt. Etna in Sicily ... , and in the postglacial lavas of Iceland. These lavas cover periods of 2300 and 4000 years respectively.

Further back in time, Hospers shows from his own data and that of Roche (1951), Bruckshaw and Robertson (1949) and Bruckshaw and Robertson (1954) that the Miocene, Pliocene and Pleistocene rocks of Iceland and North-Western Europe have a mean direction of

\begin{tabular}{|c|c|c|c|c|c|c|c|}
\hline Formation & & $N$ & $R$ & $\Phi$ & $\theta$ & $\alpha$ & $\begin{array}{c}\text { Angle } \\
\text { with the } \\
\text { dipole } \\
\text { field }\end{array}$ \\
\hline \multirow[t]{2}{*}{$\begin{array}{l}\text { Miocene lavas } \\
\text { of Iceland }\end{array}$} & $\begin{array}{l}\text { Mean } \\
\text { direction }\end{array}$ & 102 & 88.37 & 1.5 & +77.8 & 5.5 & 1.1 \\
\hline & $\begin{array}{l}\text { Theoretical } \\
\text { dipole field }\end{array}$ & & & 0 & +88.0 & & \\
\hline \multirow{2}{*}{$\begin{array}{l}\text { Columbia River } \\
\text { Basalts } \\
\text { (Miocene to } \\
\text { Pliocene) }\end{array}$} & $\begin{array}{l}\text { Mean } \\
\text { direction }\end{array}$ & 76 & 70.19 & 2.1 & +63.1 & 2.9 & 2.5 \\
\hline & $\begin{array}{l}\text { Theoretical } \\
\text { dipole field }\end{array}$ & & & 0 & +65.0 & & \\
\hline
\end{tabular}
magnetisation consistent with a geocentric axial dipole, which may however have reversed in polarity several times. In Table 1 Hospers' results from the Miocene of Iceland are quoted as an example. A similar result is given by the Miocene and Pliocene lavas of the Columbia River region in Oregon, and this is shown in Table 1 for comparison.

Table 1. The magnetisation of the Miocene lavas of Iceland and the Columbia River basalts.

Thus for the past twenty million years the Earth's field in Oregon, Iceland and North-west Europe has been similar to that of a geocentric axial dipole, and the magnetic pole ... has been coincident with the geographic pole. This is shown in Tables 2 and $3 \ldots$

\section{[31] 4. Polar movement in Pre-Miocene Times:}

\section{Observations from . . . N. W. Europe ....}

The results from Western Europe and in particular those from Britain are the most complete and are considered first. They are summarized in Table 2 and shown in Fig. 1.

(i) Lower Tertiary. The Antrim basalts of Eocene age in Ireland and a group of Oligocene intrusives from the Auvergne have declinations east of the geographic meridian, and dips less than the present dip of the magnetic field. The magnetic poles are near the present position of the New Siberian islands.

(ii) Triassic. Clegg, Almond and Stubbs (1954) have reported results from nine sites in the Keuper marls and sandstones of England. The mean magnetic direction calculated from their results is northeasterly with positive dip. The pole position consistent with this magnetisation is near the present city of Vladivostok. 
Table 2: The pole positions given by palaeomagnetic results from ... N. W. Europe.

[In Table 2] $\mathrm{F}$ is the declination in degrees east of geographic north; è is the magnetic dip; á is the error in the mean direction at $P=0.05 ; \mathrm{d} m$ and $\mathrm{d} p$ are the semi-axes of the oval error area round the pole position at the same probability. In most cases the pole position has been calculated by the authors to whom references is made. In a few cases the pole position has . . . been calculated . . . by the present author; these cases are indicated by an asterisk. [29]

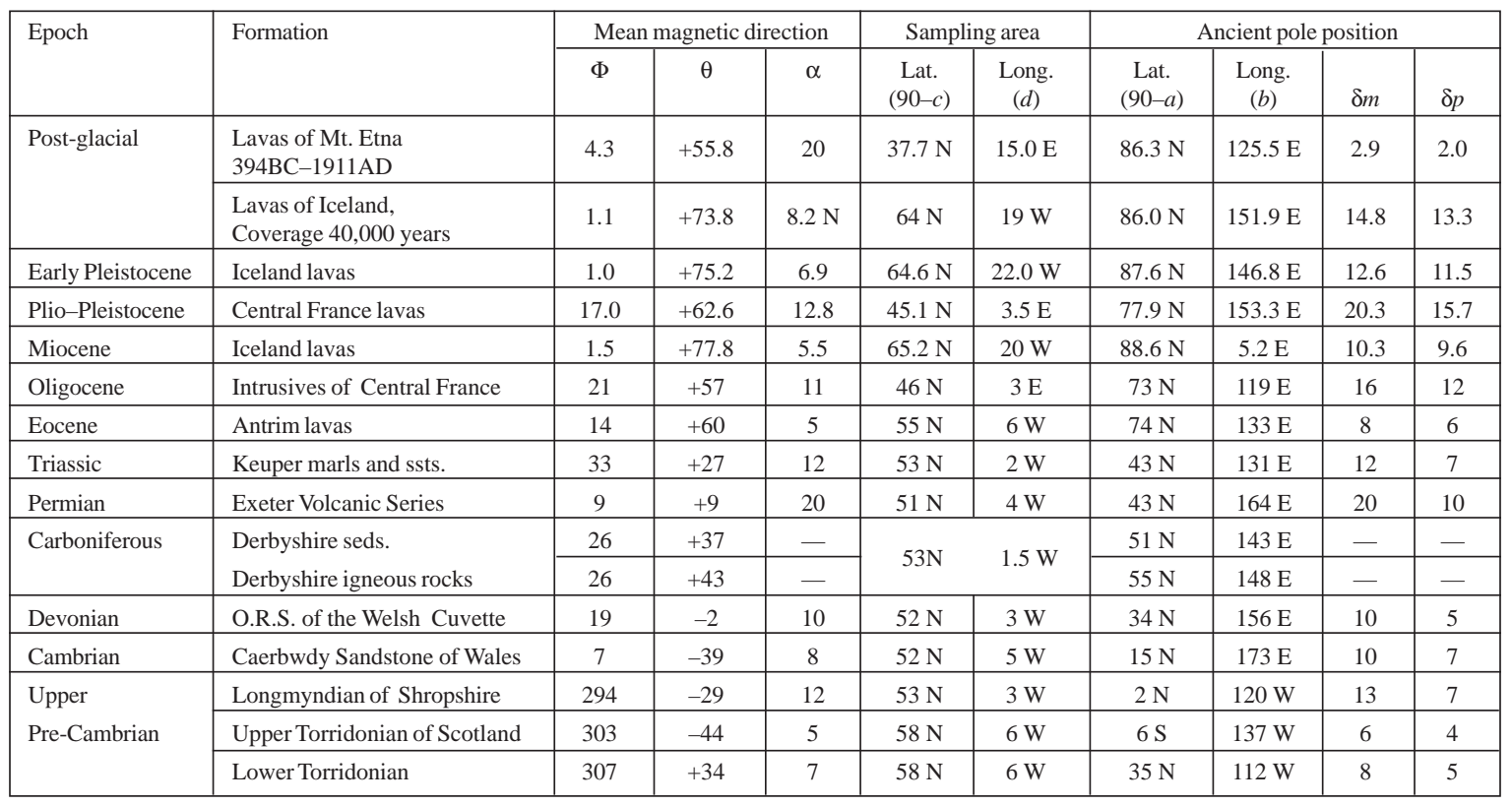

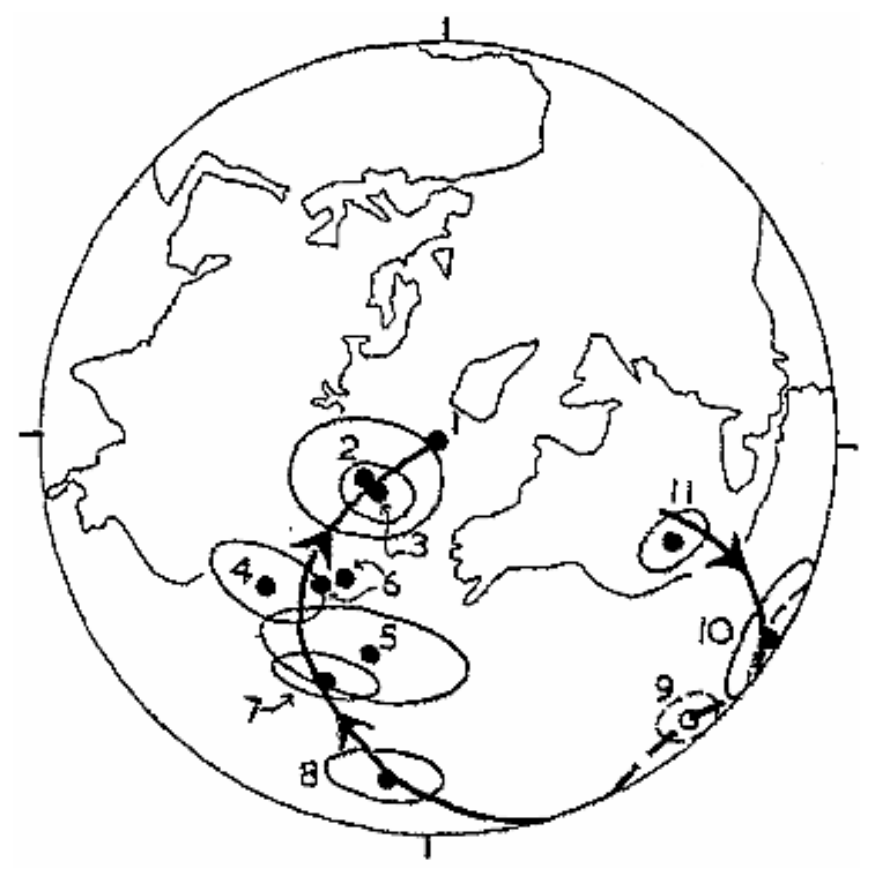

Fig. 1. The pole positions given by palaeomagnetic data from $N$. W. Europe. The projection used is Lambert's Azimuthal Equal Area projection. All poles are in the Northern Hemisphere except for the Upper Toridonian which is marked by an open circle. The approximate path of polar movement is given in a thick line which is dotted when in the Southern Hemisphere. A zone is marked around each pole which is the error area at $P=0.05$. The poles are numbered as follows: 1. Upper Tertiary, Pleistocene and Recent, individual determinations within this group have been given previously by HOSPERS (1955); 2. Oligocene; 3. Eocene; 4. Triassic; 5. Permian; 6. Carboniferous (two points); 7. Devonian; 8. Cambrian; 9. Upper Torridonian; 12. Lower Torridonian. (iii) Permian. Creer (Creer et al., 1954) has obtained the directions from 5 sites in the Exeter Volcanic Series of Devonshire. The declinations at all sites are slightly east of north, and the dips are low. The pole position is the present situation of Colorado.

(iv) Carboniferous. Belshé (in Runcorn, 1955a) has measured sedimentary and igneous rocks from the Lower Carboniferous of Derbyshire. The declinations are easterly with intermediate to low dips, The mean pole position is near the island of Sakhalin, but the data necessary to calculate the error area round this has not yet been published.

(v) Devonian. Specimens measured by Creer from 14 sites in the Old Red Sandstone of the Welsh cuvette have directions not very different from the Exeter [32] traps, except that the declinations are rather more easterly, The pole position is south east of Japan.

(vi) Cambrian. Two sites [examined by Creer [in Creer et al. (1954)] in the Caerbwby Sandstone in Pembrokeshire have easterly declinations with intermediate negative dip. The pole is in the West Pacific just north of the Equator.

(vii) Longmyndian. Creer [Creer et al. (1954)] in gives the mean direction from 13 sites located in this upper Pre-Cambrian sandstone series of Shropshire as north-easterly with negative dip. The group is usually correlated with the Torridonian sandstone series.

(viii) Upper Torridonian Sandstone Series [examined in Irving (1954)]. The Torridonian Sandstone has two predominant directions of magnetisation. Samples from 81 sites in the upper 14000 feet have north-westerly declinations with negative dips. The pole position is in the central Pacific near to the pole calculated from the Longmyndian results.

(ix) Lower Torridonian. Samples from 13 sites from the basal 2000 feet of the Torridonian Sandstone Series have north-westerly magnetisation with positive dip. The pole is in the present situation of Colorado (Irving, 1954). 
[33] Table 3: Pole positions obtained from palaeomagnetic observations in North America, India and Australia.

\begin{tabular}{|c|c|c|c|c|c|c|c|c|c|c|}
\hline \multirow[t]{2}{*}{ Epoch } & \multirow[t]{2}{*}{ Formation } & \multicolumn{3}{|c|}{ Mean magnetic direction } & \multicolumn{2}{|c|}{ Sampling area } & \multicolumn{4}{|c|}{ Ancient pole position } \\
\hline & & $\Phi$ & $\theta$ & $\alpha$ & $\begin{array}{l}\text { Lat. } \\
(90-c)\end{array}$ & $\begin{array}{l}\text { Long. } \\
\qquad(d)\end{array}$ & $\begin{array}{l}\text { Lat. } \\
(90-a)\end{array}$ & $\begin{array}{l}\text { Long. } \\
(b)\end{array}$ & $\delta m$ & $\delta p$ \\
\hline $\begin{array}{l}\text { Upper Tertiary } \\
\text { (Miocene and } \\
\text { Plicene) }\end{array}$ & Columbia River basalt & 2.1 & +63.1 & 2.9 & $47 \mathrm{~N}$ & $118 \mathrm{~W}$ & $87 \mathrm{~N}$ & $40 \mathrm{E}$ & 4.5 & 3.6 \\
\hline Cretaceous & $\begin{array}{l}\text { Dakota Sandstone of Colorado } \\
\text { Plateau }\end{array}$ & - & - & - & - & - & $76 \mathrm{~N}$ & $127 \mathrm{E}$ & 11 & 9 \\
\hline Triassic & Springdale Sandstone, Arizona & - & - & - & - & - & $60 \mathrm{~N}$ & $110 \mathrm{E}$ & - & - \\
\hline \multirow{3}{*}{ Permian } & $\begin{array}{l}\text { Supai Beds, Arizona and } \\
\text { New Mexico }\end{array}$ & 150 & +3 & 5 & $35 \mathrm{~N}$ & $104 \mathrm{~W}$ & $37 \mathrm{~N}$ & $107 \mathrm{E}$ & 5 & 3 \\
\hline & Supai Beds, Arizona & 133 & +23 & 8 & $36 \mathrm{~N}$ & $113 \mathrm{~W}$ & $36 \mathrm{~N}$ & $121 \mathrm{E}$ & 9 & 5 \\
\hline & Supai Beds, Arizona & 146 & +8 & 7 & $36 \mathrm{~N}$ & $113 \mathrm{~W}$ & $39 \mathrm{~N}$ & $115 \mathrm{E}$ & 7 & 4 \\
\hline $\begin{array}{l}\text { Carboniferous } \\
\text { Pennsylvanian }\end{array}$ & Naco Sandstones, Arizona & - & - & - & - & - & $49 \mathrm{~N}$ & $120 \mathrm{E}$ & 8 & 4 \\
\hline Silurian & Rosehill beds of Maryland & 322 & -85 & 5 & $40 \mathrm{~N}$ & $78 \mathrm{~W}$ & $19 \mathrm{~N}$ & $138 \mathrm{~W}$ & 6 & 4 \\
\hline Cambrian & Tapeats Sandstone, Arizona & - & - & - & - & - & $22 \mathrm{~S}$ & $153 \mathrm{~W}$ & - & - \\
\hline $\begin{array}{l}\text { Mesozoic, } \\
\text { probably Jurassic }\end{array}$ & Dolerite sills of Tasmania & 325 & -85 & 4 & $42 \mathrm{~S}$ & $147 \mathrm{E}$ & $50 \mathrm{~N}$ & $23 \mathrm{~W}$ & 8 & 8 \\
\hline $\begin{array}{l}\text { Cretaceous and } \\
\text { Eocene }\end{array}$ & Deccan Traps of India & 329 & -56 & 10 & $18 \mathrm{~N}$ & $74 \mathrm{E}$ & $28 \mathrm{~N}$ & $78 \mathrm{~W}$ & 15 & 10 \\
\hline
\end{tabular}

\section{Polar Movement in Pre-Miocene Times: \\ Observations from other Parts of the World}

The results are summarised in Table 3 and Fig. 2. The results

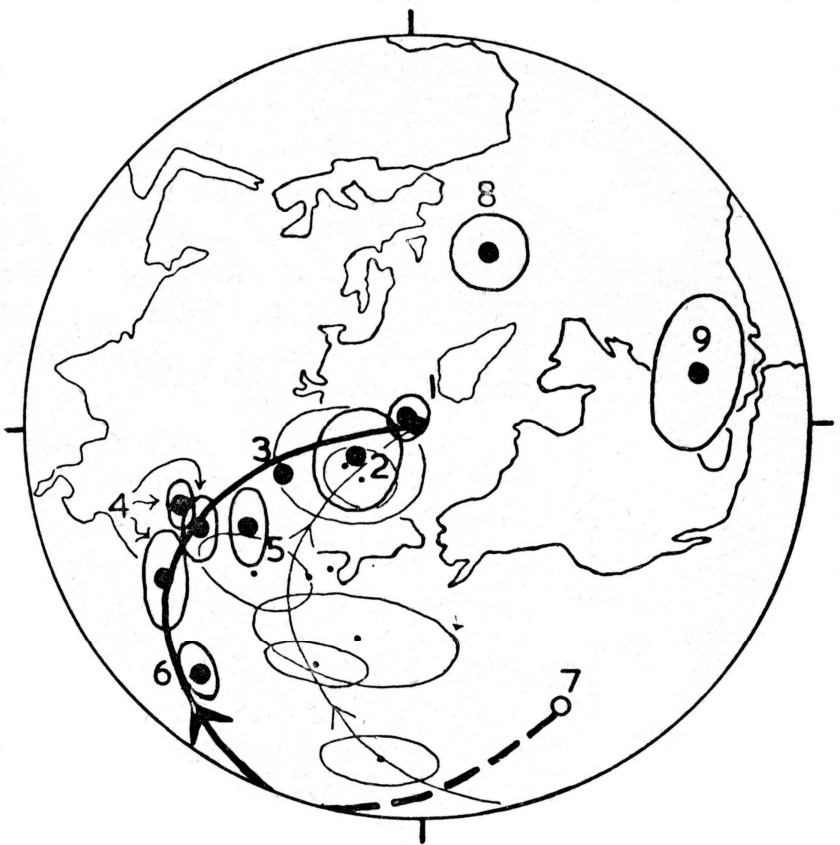

Fig. 2. The ancient pole positions given by palaeomagnetic observations from North America, India and Australia. - All poles are in the Northern Hemisphere except one, which is marked by an open circle. The error zones are like those in Fig. 1. The poles obtained from the European results are added in thinner lines for comparison. The pole positions for North America are as follows: 1. Upper Tertiary and present pole; 2. Cretaceous; 3. Triassic; 4. Permian; 5. Carboniferous; 6. Silurian; 7. Cambrian. The approximate path of polar movement is marked by a thick black line. Pole position 8 is from the Tasmanian dolerites and 9 from the Deccan traps. from the European region ... are shown by thinner lines to facilitate comparison.

A) North America

(i) Cretaceous. Runcorn (1955b) has given the pole position calculated from magnetic directions measured in specimens from the Dakota Sandstone as lying near to the New Siberian Islands.

(ii) Triassic. Runcorn (1955b) has given the pole position as lying in Siberia north of Lake Baikal.

(iii) Permian. Results obtained by three different workers are available from the Middle Permian Supai red beds of Arizona and New Mexico. The pole position (in North-east China) calculated from Graham's data (1955) is closely similar to that given independently by Runcorn (1955) and Doell (1955).

(iv) Carboniferous. Runcorn (1955b) has given the pole position consistent with the magnetisation of the Naco Sandstones of Pennyslvannian age as lying in North China.

(v) Silurian. The mean magnetisation of the Rosehill beds of Maryland in north-westerly with negative dip (Graham, 1949), and the pole positions is in the Pacific east of the Philippines.

(vi) Cambrian. The pole position calculated from some results from the Tapeats Sandstone is in the Central Pacific, south of the Equator (Runcorn in Day and Runcorn, 1955).

It is noteworthy that these pole positions are all to the west of the path of polar movement given by the magnetic data from Europe.

\section{B) Australia}

The magnetisation of samples from thirty sites in the dolerite sills of Tasmania is almost vertical (Blackett, quoted by Jaeger and Joplin (1955) and Irving (1956)) and the pole position obtained lies to the west of Ireland. The sills were intruded sometime during the Mesozoic, probably in the Jurassic. The pole position is at least $50^{\circ}$ away from any of the Mesozoic poles given by observations from Europe or North America. 


\section{C) India}

Samples from seven sites in the Deccan Traps which are of Cretaceous or Eocene age have magnetic declinations to the northwest with negative tlip. Full details are given in the appendix to this paper since these results have not been published before. The pole position is east of Florida and is $60^{\circ}$ or more away from the contemporary poles given by observations from Europe and North America.

\section{D) Other observations}

A number of measurements have been made on other rock formations ..., but the age relations of these are not sufficiently precise to be discussed here.

\section{Comparison of Palaeomagnetic Results with the Palaeoclimatic Evidence from the same Region}

It has been pointed out in the introductory remarks, that if it is true that on average the Earth's rotational and magnetic axes have always coincided, then the latitude as deduced from palaeoclimatology at any place at any time should be consistent with the latitude deduced from the palaeomagnetic observations from rocks laid down at the same place at the same time. The geomagnetic latitude is obtained from equation (7). This point is now discussed.

Some of the characteristics of rocks may be regarded as indicative of the climatic conditions which existed at the time they were deposited, continental deposits being the most interesting from this point of view. For example:

(i) Abundant plant remains and coal seams indicate heavy rainfall and swamp conditions, such as are found in present day equatorial, monsoonal and temperature wet zones.

(ii) Dune bedded sandstones and red marls with sun-cracked surfaces are indicative of regions of low seasonal rainfall which are bare of vegetation for much of the year, such as the present tropical and mid-latitude deserts. Salt beds require low rainfall and high evaporation for their accumulation.

(iii) Tillites with scratched erratics were deposited by glacial activity which requires low mean temperature and, in particular, low summer temperatures and heavy precipitation. These conditions occur most frequently in high latitudes. For long periods in the past, little permanent ice may have existed, but in the Permian undoubted glacial deposits occur which are contemporaneous with coral-reefs, coal, salt and desert sandstone deposits elsewhere which are indicative of warmer conditions. It is reasonable to associate most of these glacial deposits with high latitudes, and the other rock types with lower latitudes.

(iv) Coral reefs are only found outside the tropics today under exceptional circumstances and in the past may also have been limited to low latitudes.

(v) Warm climates with seasonal rainfall favour the oxidation, hydrolysis and fine division of iron compounds to produce red earths, laterite, and red or brown sediments. In cold and wet conditions, iron is leached out or remains in a state of low oxidation, producing podsol soils and grey sediments.

Clearly, there are many exceptions to such statements and, without very detailed study, all that can be done is to obtain broad climatic indications. Climate is determined by a general latitude control, on which are superposed very large variations caused by ocean currents, topography, the size of land masses, and so on. Fluctuations in solar heat will cause climatic changes, but these will be general for the whole earth, and the effect due to latitude will still remain. In the present connection it is desired to consider only the effect of latitude, so that large variations may be expected; the most that can [36] he hoped for, when comparing this evidence with the palaeomagnetic observations is either a general agreement or a gross inconsistency.

\section{(a) Britain}

The variations in geomagnetic latitudes for Britain are shown in Fig. 3 (1). The «tails» on the points correspond to the regions of confidence in Fig, 1 and the curve has been estimated by eye as a best fit to the calculated points. The time scale is approximately correct for Cambrian and later periods, but the absolute age of the older beds is unknown and the form of the earlier part of the curve is unreliable.

From Cambrian times onwards, the geomagnetic latitude is comparable with that inferred from the stratigraphical record. The sequence of Devonian red sandstones and coral reefs, Carboniferous coal forests, Permo-Triassic desert sandstones and salt deposits, Mesozoic coral reefs and warm climate plants in the Lower Tertiary, suggest a change from tropical to equatorial latitudes and then back to tropical latitudes, followed by a gradual increase in latitude to the present position.

The only discrepancy is in the Pre-Cambrian. The palaeomagnetic results for the Torridonian give latitudes of less than $40^{\circ}$, while the Sparagmitian tillite and the Dalradian Schiehallion Boulder Bed [Anderson (1923)] which may be of comparable age, are probably of glacial origin. Because of the inaccuracy of dating, however, it is not possible to compare these two sets of results strictly.

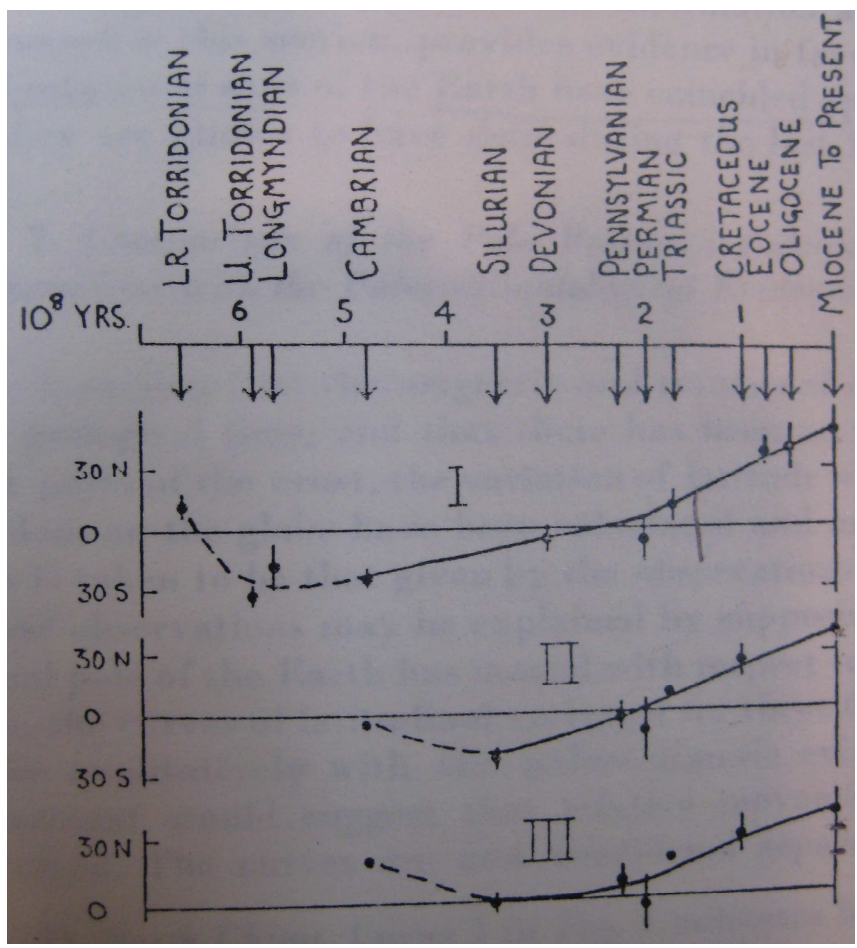

Fig. 3 - The past variations of geomagnetic latitude in Britain (I). Eastern U. S. A. (II), and Western U. S. A. (III). 
Table 4: Comparison of geomagnetic latitudes with palaeoclimatology.

\begin{tabular}{|c|c|c|c|c|}
\hline & \multicolumn{2}{|c|}{ Curve II (Eastern U. S. A.) } & \multicolumn{2}{|c|}{ Curve III (Western U. S. A.) } \\
\hline & $\begin{array}{l}\text { Geomagn. } \\
\text { latitude }\end{array}$ & Climatic indicators & $\begin{array}{l}\text { Geomagn. } \\
\text { latitude }\end{array}$ & $\begin{array}{l}\text { Climatic } \\
\text { indicators }\end{array}$ \\
\hline $\begin{array}{l}\text { Silurian to } \\
\text { Mississippian }\end{array}$ & $10-30^{\circ}$ & $\begin{array}{l}\text { Red beds, thick salt } \\
\text { and gypsum deposits, } \\
\text { coral limestones and } \\
\text { dolomites }\end{array}$ & $0-10^{\circ}$ & $\begin{array}{l}\text { Thick coral } \\
\text { limestones } \\
\text { and dolomites }\end{array}$ \\
\hline $\begin{array}{l}\text { Pennsylvanian } \\
\text { and Permian }\end{array}$ & $0-20^{\circ}$ & $\begin{array}{l}\text { Grey sediments, thick } \\
\text { coals, types laid down } \\
\text { in hot humid climates }\end{array}$ & \multirow[t]{2}{*}{$10-30^{\circ}$} & \multirow[t]{2}{*}{$\begin{array}{l}\text { Red beds with } \\
\text { thick salt and } \\
\text { gypsum deposits } \\
\text { Large coral reefs }\end{array}$} \\
\hline $\begin{array}{l}\text { Triassic and } \\
\text { Jurassic }\end{array}$ & $10-30^{\circ}$ & $\begin{array}{l}\text { Red beds with salt } \\
\text { deposits }\end{array}$ & & \\
\hline
\end{tabular}

\section{(b) The United States of America.}

Because of its large size, this region cannot, like Britain, be effectively considered as a single point, so two curves are constructed (Fig. 3) one each for the eastern (II) and western (III) parts. These curves are widely separated in the Palaeozoic when the magnetic pole lay to the west, but [37] later closed together. The palaeoclimatic comparison is best made by means of a table (Table 4) which shows that there is qualitative agreement between the climatic indications and the geomagnetic latitudes, in particular the occurrence of thick coals, indicating hot humid conditions, in the Pennsylvanian [Dunbar (1949)] and the Permian Dunkard Series in the east, and of red sandstones and salt deposits in the west are well correlated with an increase from low to intermediate geomagnetic latitude. There is one exception to this correlation, the Squantum tillite, but this is of small extent and may be the product of a mountain glacier....

The distribution of Palaeozoic faunas of North America appears to be completely unrelated to the present spread in latitude. For instance, the same species of corals in the Middle Silurian occur from the eastern states right through to the Arctic. Cephalopods also show a similar disregard for latitude [Dunbar (1949)]. This may be explained by supposing that the ancient lines of latitude were approximately at right angles to the present parallels. This view is in broad agreement with the magnetic considerations.

\section{(c) Tasmania}

The steep magnetic dips in the Tasmanian dolerites (Table 3 ) give geomagnetic latitudes of $65-80^{\circ}$ for South-Eastern Australia. The climatic evidence from this region [reviewed in David (1950)] suggests that cool conditions obtained during the later Mesozoic; in particular, there are cool-water invertebrate faunas in the Jurassic, warm-water forms so common elsewhere in the world being absent [Whitehouse (1926)]. In the Cretaceous there are strong indications of glacial activity.

\section{(d) India}

There is no definitive climatic evidence in the Tucks associated with the Deccan Traps, and no comparison with the palaeomagnetic evidence is possible.

It may be concluded that the information at present available on the points discussed in this section, provides evidence in favour of the view that the magnetic and rotational axes of the Earth have coincided approximately since the Palaeozoic, as they are known to have done during the last 20 million years.

\section{Comparison of the Pole Positions Calculated from} the European Magnetic Observations with the Palaeoclimatological Evidence, from other Parts of the World

Assuming that the magnetic and rotational axes have been coincident throughout geological time, and that there has been no relative movement between different parts of the crust, the variation of latitude with time at five areas distributed at random on the globe have been calculated and are plotted in Fig. 4. The magnetic axis is taken to be that given by the observations from North-Western Europe (§4). These observations may be explained by supposing that the geomagnetic and rotational pole of the Earth has moved with respect to the land-masses. On this supposition, the curves of latitudinal variation for these five widely scattered places, shotdd agree

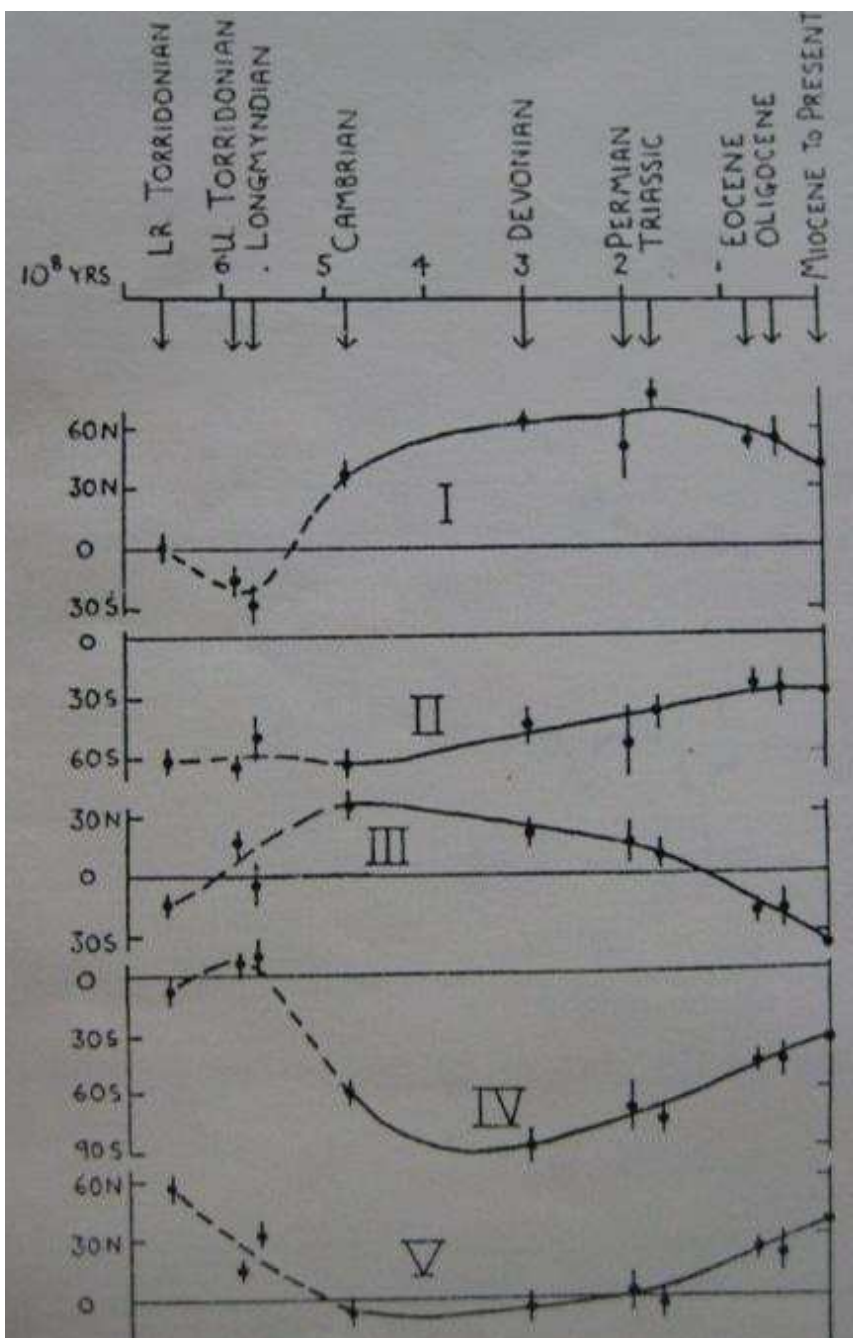

Fig. 4. - The past variation in latitude in five continents calculated from the European curve of polar wandering. - These curves are calculated for the centre of the following regions: (I) North China (Peking), (II) South Africa (Bloemfontein), (III) S. E. Australia (Canberra), (IV) Southern Brazil (Rio Grande do Sul), and (V) Eastern U.S.A. (Harrisburg). The errors are obtained from the errors in determination of the positions of the ancient poles and represent the limits within which the latitude lay at a probability of $95 \%$. 
qualitatively with the palaeoclimatic evidence at each place: any lack of agreement would suggest that relative movement between the landmasses has occurred. The curves are now considered separately.

1) North China. Curve I in Fig. 4 indicates high latitudes continuously for the later Palaeozoic and Mesozoic. The contrast with the stratigraphical record is complete. From the Carboniferous onwards there is a full sequence of continental [38] deposits exhibiting characteristics uniformly indicating low or intermediate latitudes. Thick coal seams with characteristics suggestive of accumulation in a warm climate occur throughout, but are specially common in the Carboniferous and Permian; red sandstones, shales and marls are common in the Triassic and Jurassic; bauxitic shales and gypsiferous beds also occur. Large reptiles flourished. Glacial beds which are found elsewhere in the world in the Carboniferous and Permian, and which would be anticipated from the high latitude, are entirely absent.

2) South Africa. The widespread Upper Carboniferous tillites of the Dwyka Series were deposited by an ice-sheet of continental dimensions [Du Toit (1937, p. 269)]. The Permian Ecca Series probably accumulated in a wet but rather cold climate since fireclays of lateritic composition are absent, fresh felspars occur in the grits, and much of the fossil wood has annual rings. Red and purple strata appear in the Permo-Triassic Beaufort beds. Coals reappear at the base of the Stormberg Series, but the overlying red beds and the aeolian Cave Sandstone and Jurassic age suggest conditions of accumulation comparable to present day tropical and mid-latitude deserts. The Curve II of Fig. 4 gives a latitude of about $50^{\circ}$ for the Dwyka glaciation, and glaciers are known to have been developed in the Pleistocene [39] down to this latitude. The later part of the curve does not differ substantially with the palaeoclimatic evidence.

3) South Eastern Australia. One of the striking characteristics of the stratigraphy of S.E. Australia is the occurrence of glacial tillites, varves and fluvio-glacial beds in the Upper Carboniferous and Lower Permian. In the Jurassic, conditions were generally cool, and in the Cretaceous there is again evidence of glaciation (see $\S 6$ ). The low latitudes given by the Curve III of Fig. 4 from Permian to Tertiary are in contrast to this evidence.

4) Southern Brazil and Argentina. The palaeoclimatologieal evidence is comparable with that from the other southern continents. The Upper Carboniferous has thick widespread glacials followed by Lower Permian coals. In the later Permian, conditions were drier and warmer with red beds. Curve IV. Fig. 4, gives polar latitudes from Devonian to Triassic which are consistent with the glacial beds but not with the later coals and red beds.

5) Eastern U.S.A. The palaeoclimatologieal sequence is comparable with that in Europe and has been discussed previously (Table 4). The Devonian to Carboniferous, and the later Mesozoic parts of Curve V of Fig. 4 are approximately compatible with this evidence, but the predicted latitude from the palaeomagnetie evidence for the Triassic is too low.

This comparison would not have yielded greatly different results if any other set of randomly distributed points had been selected. For North China and South Eastern Australia the contrast between the palaeomagnetic latitude given from the N.W. European observations, and the local palaeoclimatology is complete; for Southern Brazil and Eastern U.S.A. some of the evidence is compatible and some conflicts; for South Africa there is no substantial disharmony. In the last case, it seems possible to explain the palaeomagnetic evidence from N.W. Europe by the simple hypothesis of polar wandering as described in $\S 1$. However, considering the evidence from the other four regions, this hypothesis alone is inadequate, and some relative movement between N.W. Europe and these regions seems also to be indicated.

\section{Conclusions}

The geomagnetic field has approximated closely to a geocentric axial dipole since the Miocene. Moreover, the correlations between the latitude given by the magnetic data from a particular region and that indicated by the climatic conditions of deposition inferred from the stratigraphic sequence in the same region, suggests that it is reasonable to suppose that the Earth's field has maintained this predominantly axial dipole character at least since the Palaeozoic.

The positions of the magnetic pole calculated on this axial dipole assumption, from the magnetisation of rocks of Pre-Miocene age, differ greatly from the present geographic pole, polar wandering having occurred. The poles given by data from four continents do not however agree one with another. The discordance between the poles calculated from the magnetic data from Palaeozoic rocks of North America and Europe is particularly notable, since it is shown by several determinations made by independent observers. Agreement could be achieved by supposing that North America was closer to Europe in the Palaeozoic and early Mesozoic.

Using the dipole assumption again, a comparison of the latitudes predicted [40] for different parts of the world from the pole position deduced from the European data, with the palaeoclimates in these parts, also yields the result that relative movement of the continents in the past has occurred.

These conclusions depend for their validity on the fundamental supposition that the Earth's field, when considered over periods of times of the order of a thousand years or so, has approximated to that which would be produced hy a geocentric axial dipole. If this assumption is abandoned the positions of the pole given in this paper cease to have any significance. There is however very substantial palaeomagnetic and palaeoclimatic evidence in favour of this assumption, and it is also in agreement with modern ideas concerning the origin of the Earth's magnetic field.

\section{Appendix}

The magnetisation of specimens from the Deccan traps - These are observations obtained from the Deccan Traps of India, which are of Cretaceous or Eocene age. Grateful acknowledgement is made to Dr. M. S. Krishnan, Director of the Indian Geological Survey, and to officers of this Survey who very kindly collected these specimens. The samples were obtained from different horizons, over a considerable area, stretching 200 miles from Poona to Belgaum. The results which are summarised in this table were obtained when the author was a member of the Department of Geophysics, Cambridge.

\begin{tabular}{|l|c|r|c|}
\hline \multirow{2}{*}{$\begin{array}{l}\text { Localities of } \\
\text { Collection }\end{array}$} & \multicolumn{2}{|c|}{ Direction of Magnetisation } & $\begin{array}{c}\text { Intensity of magnetisation } \\
\text { in elecelectromagnetic } \\
\text { units per c.c. X } 10^{-4}\end{array}$ \\
\cline { 2 - 3 } Yerowda & 139 & + & 4.0 \\
Yerowda & 150 & 44 & 3.5 \\
Yerdowda & 160 & + & 7.4 \\
Poona & 140 & 50 & 23.0 \\
Pashan & 201 & + & 7.2 \\
Kateru & 294 & 58 & 91.2 \\
Belgaum & 354 & +54 & 60.3 \\
& & +78 & \\
& & - & \\
& & - & \\
\hline
\end{tabular}




\section{References}

Anderson, E.M., 1923. Quarterly Journal of the Geological Society of London, v. 79, pp. 423-445.

Bruckshaw, K.M. and Robertson, E.I., 1949. The magnetic properties of tholeiitic dykes of N.W. England. Monthly Notes of the Royal Astronomical Society, Geophysical Supplement, v. 5, pp. 308-320.

Bruckshaw, K.M. and Vincenz, S.A., 1954. The permanent magnetism of the Mull lavas. Monthly Notes of the Royal Astronomical Society, Geophysical Supplement, v. 6, pp. 579-589.

Bullard, E.C., 1949. The magnetic field of the Earth. Proceedings of the Royal Society, Series A, v. 197, pp. 433-453.

Clegg, J.A., Almond, M. and Stubbs, P.H.S., 1954. The remanent magnetism of some sedimentary epochs in Britain. Philosophical Magazine, Series 7 , no. 45 , pp. $583-598$.

Creer, K., Irving, E. and Runcorn, S.K., 1954. The direction of the geomagnetic field in remote epochs in Great Britain. Journal of Geomagnetism and Geoelectricity, 6, 163-168.

David, T.W.E., 1950. Geology of the Commonwealth of Australia. London: Arnold.

Day, A.A. and Runcorn, S.K., 1955. Polar wandering: some geological, dynamical and palaeomagnetic aspects. Nature, v. 176, pp. 422-426.

Doell, R.R., 1955. Palaeomagnetic study of rocks from the Grand Canyon of the Colorado River. Nature, v. 176, pp. 1167.

Du Toit, A.L., 1937. Our Wandering Continents. London: Oliver \& Boyd.

Dunbar, C.O., 1949. Historical Geology. New York: John Wiley.

Fisher, R.A., 1953. Dispersion on a sphere. Proceedings of the Royal Society, Series A, v. 217,pp. 295-306.
Gold, T., 1955, Instability of the Earth's axis of rotation. Nature, v. 175, pp. $526-529$.

Graham, J.W., 1949. The stability and significance of magnetism in sedimentary rocks. Journal of Geophysical Research, v. 54, pp. 131167.

Graham, J.W., 1955. Evidence of polar shift since Triassic times. Journal of Geophysical Research, v. 6, pp. 329.

Hospers, J., 1955, Rock magnetism and polar wandering. Journal of Geology, v. 63 , pp. $59-73$.

Irving, E., 1954 (submitted). The Palaeomagnetism of the Torridon Sandstone Series. PhD dissertation: awarded MSc. The University of Cambridge.

Irving, E., 1956. The magnetisation of the Mesozoic dolerites of Tasmania. Papers and Proceedings of the Royal Society of Tasmania, v. 90, pp.157168.

Jaeger, J.C. and Joplin, G., 1955. Rock magnetism and the differentiation of a dolerite sill. Journal of the Geological Society of Australia, v. 2, pp. 119.

Roche, A., 1951. Sur les inversions de l'aimantation remanantes des roches volcaniques dans les monts d'Auvergne. Comptes rendus de l'Académie des Sciences, Paris, v. 233, pp. 1132-1134.

Runcorn, S.K., 1954. The Earth's core. Transactions of the American Geophysical Union, v. 35, pp. 49-63.

Runcorn, S.K., 1955a. Rock magnetism-geophysical aspects. Philosophical Magazine (Supplement, Advances in Physics), v. 4, pp. 244-291.

Runcorn, S.K., 1955b. Palaeomagnetism of sediments from the Colorado Plateau. Nature, v. 176, pp. 505.

Whitehouse, F.W., 1926. Cretaceous ammonoidea of eastern Australia. Memoirs of the Queensland Museum, v. 5, pp. 195-212. 